export of the chief minerals, gold and copper, has decreased, but there are good prospects of development and increased production at Port Moresby and Misima Island. The value of the gold was $26,766 l$. in 1919 as against $33,512 l$. in 1918. Copper was worth 11,537 . in 1918 , but only $1653 l$. in 1919 .

The actual revenue of the Territory, including a grant of $30,000 l$. from the Commonwealth of Australia, amounted during the year to $103,120 \%$. The expenditure was 102,961 . Thus a surplus of 18,7781 . in 1918 was increased by about $159 l$. to 18,937 .

The European population was 1007. Coloured persons other than Papuans were 304, of whom 217 were mission teachers. There were also 340 police and $82 \mathrm{I}$ village constables of various races. During the year 8610 native labourers were recruited, to whom more than $40,000 l$. was paid in wages.

The actual native population is uncertain. A quarter of a million is suggested by the Acting Medical Officer. In some districts the number is increasing, but around Port Moresby the physique of the natives appears to be deteriorating through the adoption of European food and clothing. In a supplement to the report the Rev. J. B. Clark, of the London Missionary Society, gives a hopeful account of the progress of the natives. Boys leaving school become telephone operators and clerks, and some of the native churches are capable of self-government. The relations of the natives with the Government have been, on the whole, satisfactory. A few affrays and murders have taken place in remote districts, but there has been a general prevalence of respect for law and order. An incident in the Chirima district of the Mambare Division is typical of dealings with the natives. The attempt of a patrol to arrest a native led to an attack in which another native was killed and a woman and a boy were wounded. The natives were afterwards pacified by the Resident Magistrate of the Kumusi Division. The pacification involved some difficulty and risk, as the natives took to the bush and refused to parley unless the officers, Messrs. Blyth and Fowler, went to them unarmed and alone. The officers took the risk, and after a conference the confidence of the natives was restored.

A valuable scientific section of the report is found in the supplements contributed by the Resident Magistrates and patrol officers, the Medical Officer, the Government Geologist, and the Agricultural Expert.

A paper of considerable ethnological interest by the late W. Beavers ( $c f$. Nature, February I9, I920) is also included. It deals with the use of emblems or insignia of man-killing among certain tribes of the north-western part of Papua. A preface gives an account of the ceremonious reception of the mankiller by his village, and of his life on his return. The insignia consist of various decorations of shellrings, feathers, dog-teeth, and similar articles. There are also other distinctions not of a material nature, such as taking the name of the individual slain, prohibition of his flesh to the slayer, skull trophies, and mutilations. A further account describes the Kortopo ceremony by which the privileges of the man-killer are passed on to others. The custom is now decadent, and the slaying of a fat pig is sufficient justification for the wearing of the emblems.

The polyglot character of the tribes of Papua is shown by an index of the vocabularies of native dialects contained in the annual reports from 1889 to 1918 . There are more than 450 titles. The present report increases them by fourteen.

SiDNEY H. RAY.

\section{Ancient Egyptian Survivals in Modern Egypt.}

$A \mathrm{~N}$ interesting lecture upon the above subject was delivered on behalf of the Egypt Exploration Society at the rooms of the Royal Society, Burlington House, on February 23 by Prof. C. G. Seligman.

Two classes of survival from ancient Egypt may be distinguished, namely, (I) beliefs and (2) certain technological objects and processes. Each group embraces, on one hand, survivals in situ, such as certain beliefs connected with the calendar, and a ceremony in which a sacred boat takes a prominent part; and, on the other, examples from other parts of Africa in which Egyptian customs, often modified by later cultural waves, have persisted for a longer or shorter period. As examples may be cited certain medieval graves of Senegal, and probably the funeral customs of a number of tribes of Equatoria, as well as the belief in multiple souls found in the Southern Congo and West Africa.

A striking example is found in the persistence of old beliefs attached to certain days. In the Sallier papyrus, which dates from the time of Rameses II., or possibly of his successor, Athyr igth is marked as one of the days "to beware" : "storms are engendered in the skies; do not travel on the river neither up nor down; do not . . . at all on this day." In a modern calendar for 1878 the instructions for $\mathrm{Zu}$ 'lHeggeh 4th, which corresponds to the Coptic Hatour, i.e. Athyr Igth, is: "Avoid travelling on the Mediterranean." Thus we have persisting for some 3500 years the tradition that this day is unlucky for travellers.

Another interesting example mentioned by Prof. Seligman was that of a boat which is kept at Luxor, at the present day on the roof of a mosque, but a few years ago suspended in a tree. At stated times the boat is brought down, decorated with green branches, placed upon a cart, filled with children, and taken in procession round the town. There are three boat processions in Luxor every year, one to commemorate the birthday of Abu'l Heggag, the patron saint of Luxor, and the others on the birthday of the Prophet and the beginning of Ramadan.

These beliefs and ceremonies are of interest, not only because the period over which they have persisted is longer than that bridged by the host of beliefs and practices that constitute the folk-lore of other peoples, but also because it is possible to adduce perfectly definite evidence of their direct continuity over a very much longer period of time. The interest of the boat ceremony is even greater; Prof. Seligman thought a fairly good case could be made out for a number of boat ceremonies still performed in the East-e.g. one he had himself witnessed in Ceylon-having originated in Egypt and been carried eastward by Islam, just as was the Malay alphabet.

\section{University and Educational Intelligence.}

CAMBridge.--Trinity College has offered to establish a prælectorship in geodesy if satisfactory arrangements are made for the institution in the University of a school for research in that subject. This is a very welcome move forward in a scheme which has been under consideration for some time to found a centre of geodetic teaching, and ultimately a Geodetic Institute, at Cambridge.

It is proposed to offer a diploma in hygiene which will suit the needs of medically qualified students of public health whose qualification is foreign and not registrable in Great Britain.

No. 2679 , voL. IO7] 
Grants have been made for the Gordon Wigan Fund towards plant-breeding, museum cases for insects, standard slides for petrology, and a solar radiation recorder for the botanical school. A recommendation is put forward to increase the value of the Balfour studentship from $250 l$. to $300 l$. a year.

The London County Council Education Officer announces that a lecture on "Chemical Technology" will be given by Dr. M. O. Forster at Salters' Hall, St. Swithin's Lane, E.C.4, on Saturday, March 5, at ro.30 a.m.; and one on "The Romance of Science" by Sir W. H. Bragg at University College, Gower

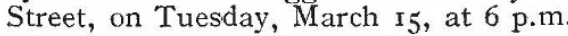

$I_{N}$ an answer to a question concerning the London University site, the Chancellor of the Exchequer has made the following statement :- "In October last the University of London accepted the offer made by the Government in the preceding April of a site behind the British Museum and the site has been purchased. For the funds required for building the University headquarters the University must look primarily to private generosity, but it will be open to the University Grants Committee to supplement local contributions if the funds at their disposal allow." The purchase price of the site is $425,000 l$.

THE University of Melbourne has issued a statement with reference to an important lectureship and demonstratorship just established in natural philosophy. The lecturer will deliver the lectures in natural philosophy to medical students, and be generally responsible for the organisation of the teaching of this part of the work of the natural philosophy department. He will be appointed in the first instance for a period of five years, the appointment to date from March I, I922. The salary of the lecturer will be 750 l. per annum, payable monthly. Candidates should not be above thirty-five years of age, and applications for the post should be lodged with the Registrar, University of Melbourne, by April $\mathrm{I}_{5}$ next. Facilities for original research in physics will be given. The Grayson gratings (see Proc. Roy. Soc. Vict., September, 1917) were ruled in a workshop of the natural philosophy department of the University.

A COURSE designed to meet the needs of qualified medical practitioners who may wish to obtain the diploma in public health of the Royal Colleges of Physicians of London and Surgeons of England has been arranged by the committee of the Technical College, Bradford, and the Health Committee of the City Council. For this purpose the Technical College has recently been placed upon the list of recognised institutions by the Royal Colleges. The proposed course will extend over twenty-five weeks, and include lectures and laboratory work in bacteriologv and pathology and in chemistry. In connection with the course in bacteriology. Dr. W. Campbell has been appointed lecturer in bacteriology and the pathology of industrial diseases, and Dr. R. Cecil Robertson assistant lecturer and demonstrator in serology and immunology in the college. The course in chemistry will be under the direction of the head of the chemistry department of the Technical College (Dr. R. D. Abell). The recognition of the college for post-graduate work of this nature marks an important point in the development of the work of the college.

THE announcement that the Rockefeller Foundation intends to assist the medical schools of Central Europe is yet another step in the fulfilment of its purpose "to promote the well-being of mankind throughout the world." A programme is announced which provides for assistance in the rehabilitation of scientific equipNO. 2679 , VOL. IO7] ment for medical purposes, for aid in furnishing medical journals to universities, and invites the authorities of the Medical School of Belgrade University to study medical education in England and America as guests of the Foundation. These decisions are the result of investigations into medical conditions in Central Europe made by representatives of the Trust, who reported that, with the exception of Austria, all the countries in this region are suffering from a shortage of physicians; there are only nine medical schools of repute to provide medical men for some $75,000,000$ people. Belgrade is regarded as one of the strategic points in a medical campaign, so the invitation to study English and American methods has been given to the men who are responsible for its development; they have also been authorised to recommend candidates to the Foundation for fellowships for specialised post-graduate medical study. Germany is not included in the scheme, for she is considered to be adequately supplied with wellequipped medical schools. The International Health Board of the Rockefeller Foundation has come to an agreement with the Government of Czecho-Slovakia whereby the latter will borrow the services of a com. petent American public health administrator, and co-operate with the Board in the development of a national public health laboratory service, in the provision of fellowships for Czechs for public health train. ing, and the dispatch of a Czech Commission to study public health administration in England and America. Nine medical men have already been awarded fellowships, and five members of the Commission from the Ministry of Hygiene have arrived in America as guests of the Foundation.

IN an address delivered in September last to the Old Students' Association of the Royal College of Science (Lamley and Co., South Kensington, S.W.7, price 2s. 6d.), Prof. H. E. Armstrong recalled his early training at the Royal College of Chemistry as it existed in 1865 at the close of Hofmann's career as professor in that institution. The freedom of choice of study left to an independent student of those days was contrasted with the examinational restraints imposed at present on candidates for university degrees. The lecturer referred to his later studies at Leipzig under Kolbe, in the golden era of German Lern- and Lehr-freiheit, and to his early teaching experiences at the London Institution. In 1879 Prof. Armstrong entered the service of the City and Guilds of London Institute, and thus became the founder successively of the chemical departments of the Finsbury Technical College and the Central Technical College. An intimate knowledge of the educational requirements of Lcndon extending over a period of fifty years leads the lecturer to the conclusion that the Imperial College must be autonomous, and that its functions. should be restricted to the physical and mathematical sciences. Conversely, University College should be constituted as an Imperial College of Biological Science and Technology dealing with the special requirements of biology. It is suggested further that King's College should become an Imperial College of Arts and Economics. The three colleges thus reconstituted should be federated in one Imperial university. The social needs of the new university in regard to playing-fields would be met by estab. lishing the Arts College on a country site such as at Kenwood. Students' hostels would be required at the urban centres. Each college should be granted the power to confer its own degrees, but the federal scheme should be sufficiently elastic to leave a student free to attend courses at a college other than his own so that his studies "could be as broad as his heredity would permit." 